DOI: $10.32089 / \mathrm{WBH} 007$

orcid.org/0000-0002-6389-2371

\title{
Dariusz Nawrot, Józef Wiesław Dyskant, AMOR PATRIAE NOSTRA LEX. Rzecz o komandorze Stanisławie Mieszkowskim, Instytut Pamięci Narodowej Komisja Ścigania Zbrodni przeciwko Narodowi Polskiemu Oddział w Gdańsku, Gdańsk 2016, ss. 111
}

Postać komandora Stanisława Mieszkowskiego (17 czerwca 1903 r. 16 grudnia 1952 r.) oraz losy innych oficerów Polskiej Marynarki Wojennej okresu międzywojennego nie posiadają należytego miejsca w historiografii oraz w świadomości historycznej Polaków i przez wiele lat stanowiły swego rodzaju lukę historyczną ${ }^{1}$. Odradzające się państwo polskie - po 1918 r. było w stanie nie tylko odtworzyć szeroko pojęty aparat administracyjny, odbudować i rozwijać gospodarkę oraz życie kulturalne, ale przede wszystkim stworzyć funkcjonalne struktury wojskowe. Jednym z filarów nowo formowanych Polskich Sił Zbrojnych była Marynarka Wojenna (MW). Została ona utworzona rozkazem Naczelnego Wodza z 28 listopada 1918 r., prężnie się rozwijała, co skutkowało wyszkoleniem wielu oficerów i marynarzy, których służba do tej pory nie została dostatecznie opisana. Jedną z takich osób był właśnie komandor Stanisław Mieszkowski - obrońca Helu we wrześniu i październiku 1939 r., jeniec niemieckich oflagów, po wojnie m.in.: kapitan portu w Kołobrzegu, dowódca Flotylli Trałowców czy wreszcie szef Sztabu Głównego Marynarki Wojennej. W 1950 r. został aresztowany pod zarzutem szpiegostwa i skazany wyrokiem Najwyższego Sądu Wojskowego w Warszawie na karę śmierci. Pozbawiony życia strzałem w tył głowy, został potajemnie wrzucony do bezimiennego dołu.

K. Zajączkowski, Bohater obrony Helu kmdr por. Zbigniew Przybyszewski 1907-1952, Warszawa 2011. Dzieło przybliża czytelnikowi m.in. okoliczności aresztowania kmdr. Przybyszewskiego, jego pobyt w więzieniu Głównego Zarządu Informacji (GZI), przebieg procesu przed Najwyższym Sądem Wojskowym w Warszawie oraz poszukiwanie miejsca jego pochówku. 
Autorami książki poświęconej komandorowi Mieszkowskiemu są dwaj historycy: komandor dr hab. Dariusz Nawrot - wykładowca Uniwersytetu Śląskiego w Katowicach, podejmujący w swych pracach naukowych problematykę historii wojskowości oraz nieżyjący już komandor prof. dr hab. Józef Wiesław Dyskant specjalizujący się w tematyce marynistycznej, autor wielu publikacji poświęconych historii i dziejom marynarki wojennej ${ }^{3}$. Jak słusznie autorzy zauważają we wstępie: „Życie kmdr Mieszkowskiego i jego służba pod biało-czerwoną banderą to swoista egzemplifikacja losów oficerów Marynarki Wojennej II RP”. Łaciński tytuł będący życiową dewizą kmdr. Mieszkowskiego Amor Patriae Nostra Lex $x^{4}$ doskonale obrazuje czytelnikowi postawę i motto, którym się kierował w życiu - miłość do Ojczyzny.

Praca składa się ze wstępu, pięciu rozdziałów opisujących życie, służbę oraz śmierć kmdr. Mieszkowskiego oraz końcowego podsumowania. Rozdział pierwszy: Dzieciństwo i młodość (s. 10-17) jest przybliżeniem historii rodziny Mieszkowskich wraz z jej powstańczymi tradycjami ${ }^{5}$, dzieciństwa oraz wczesnej młodości Stanisława Mieszkowskiego na tle wydarzeń wybuchu I wojny światowej. Zmobilizowany do armii carskiej ojciec Stanisława - Juliusz Mieszkowski - został przydzielony do oddziału rosyjskich wojsk drogowych ${ }^{6}$ i udał się wraz z nim do Moskwy. Kolejnym miejsce stacjonowania Juliusza był Uralsk, gdzie w stopniu kapitana był odpowiedzialny za magazyny z żywnością. O podjęciu decyzji o powrocie do odradzającej się Polski zdecydowała podróż rodziny Juliusza. Sam ojciec Stanisława Mieszkowskiego, po dotarciu do Polski, po pobycie w obozie przejściowym w Baranowiczach koło Grodna zakończył wojenną tułaczkę. Pierwszym miejscem zamieszkania po powrocie były Pabianice, gdzie Juliusz Mieszkowski sprawował funkcję starosty, by następnie przez Węgrów ostatecznie osiąść w Siedlcach. Mimo zawirowań rodzinnych spowodowanych wojną Stanisław Mieszkowski był promowany do kolejnych klas, a jego zamiarem było uzyskanie matury. Plany częściowo pokrzyżowała wojna polsko-bolszewicka 1920 r., w której wraz z młodszym bratem Józefem wziął udział jako ochotnik. Początkowo bracia Stanisław i Józef Mieszkowscy pełnili służbę garnizonową w Siedlcach w ramach 22 Pułku Piechoty, a następnie

\footnotetext{
D. Nawrot, Korpus oficerski Marynarki Wojennej II Rzeczpospolitej, Warszawa 2005; idem, Zarys historii konfliktów morskich od czasów najdawniejszych do końca XVI wieku, Gdynia 2013.

3 Zob. np. J. Dyskant, Flotylle rzeczne w planach i działaniach wojennych II Rzeczypospolitej, Warszawa 1991; idem, Flotylla rzeczna Marynarki Wojennej 1919-1939, Warszawa 1994.

$4 \quad$ Pol. - Miłość ojczyzny naszym prawem.

5 Dziadek Stanisława Mieszkowskiego - Piotr Mieszkowski - brał udział w powstaniu styczniowym.

$6 \quad$ Juliusz Mieszkowski był z zawodu mierniczym.
} 
- po oddelegowaniu do obrony granic na Śląsku Cieszyńskim - 20 listopada 1920 r. zostali zwolnieni do cywila. Uzyskanie świadectwa dojrzałości w Państwowym Gimnazjum im. Hetmana Stanisława Żółkiewskiego w Siedlcach i zdanie egzaminów wstępnych pozwoliły Mieszkowskiemu na rozpoczęcie zajęć w 1923 r. w Szkole Podchorążych Piechoty w Warszawie. Niestety, autorzy nie poświęcili dużej uwagi temu etapowi życia młodego Mieszkowskiego - brakuje tu opisu zajęć odbywających się w ramach „podchorążówki”, nie przedstawiają poczynań oraz osiągnięć Mieszkowskiego tak bardzo pragnącego zostać zawodowym żołnierzem.

Rozdział drugi: Pod bandera II Rzeczypospolitej (s. 17-34) opisuje początki powstania Oficerskiej Szkoły Marynarki Wojennej (OSMW), przybliża okoliczności oraz postaci tworzące wspomnianą szkołę. Zaczynając od Tymczasowych Kursów Instruktorskich dla Oficerów Marynarki Wojennej, na zrębach której powstała OSMW, czytelnik zapoznaje się m.in. z kolejnymi zajęciami, jakie odbywali uczestnicy kursu, wykładowcami oraz ówczesnymi problemami, z jakimi borykała się nowo powstała uczelnia. Autorzy dużą uwagę poświęcili Adamowi Mohuczemu ${ }^{7}$ komendantowi Tymczasowych Kursów Instruktorskich dla Oficerów MW, przedstawiając jego biografię oraz wspomnienia o komandorze. Na następnych stronach książki przywoływane są kolejne zasłużone postaci dla Marynarki Wojennej II RP, takie jak: kmdr ppor. Heliodor Laskowski ${ }^{8}$ czy też „Książę Polesia” kmdr ppor. Witold Zajączkowski ${ }^{9}$. Trudno szukać tu informacji bezpośrednio związanych z osobą Mieszkowskiego, jednak zastosowanie zabiegu wprowadzającego czytelnika w świat nowo powstającej MW daje nam możliwość poznania realiów, w jakich przyszło funkcjonować naszemu bohaterowi oraz wielu jemu podobnym. Przykładowo, zdaniem autorów niekorzystny wpływ na realizację programu nauczania OSMW miały takie czynniki, jak: braki kadrowe, logistyczne czy też zaopatrzeniowe. Dzięki zaś staraniom instruktorów wyniki uzyskiwane przez kursantów były zadowalające. Mimo trudności Mieszkowski uzyskuje kolejne awanse (stopień porucznika

Adam Mohuczy (ur. 1891 - zm. 1953) kontradmirał i morski oficer okrętów nawodnych, uczestnik wojny polsko-bolszewickiej 1920 r. oraz kampanii polskiej 1939 r. W latach 19391945 więzień niemieckich oflagów XVIII A Lienz oraz II C Woldenberg. W 1945 r. powołany na dyrektora Oficerskiej Szkoły Marynarki Wojennej, w latach 1945-1947 pełniący obowiązki dowódcy Marynarki Wojennej. Aresztowany w 1945 r. i skazany pod zarzutem dokonania sabotażu na 13 lat pozbawienia wolności. Zmarł w więzieniu w Sztumie w 1953 r., zrehabilitowany w $1957 \mathrm{r}$.

8 Heliodor Laskowski (ur. 1898 - zm. 1936) komandor podporucznik Marynarki Wojennej RP, modernizator i twórca polskiej artylerii nadbrzeżnej.

$9 \quad$ Witold Zajączkowski (ur. 1892 - zm. 1977) kmdr Marynarki Wojennej RP. W latach 1927-1939 dowódca Flotylli Rzecznej Marynarki Wojennej, uczestnik kampanii polskiej 1939 r. W latach 1941-1942 szef Morskiej Misji Werbunkowej w Kanadzie. 
marynarki w sierpniu 1929 r.) oraz pełni funkcje wykładowcze (m.in. wykładowcy regulaminów morskich, sygnalizacji czy też organizacji marynarki wojennej). W 1929 r. zostaje skierowany do francuskiej École des Officiers Canonniers w Tulonie i po prawie rocznym pobycie uzyskuje dyplom tejże uczelni.

Nawrot i Dyskant szczegółowo opisują awanse oraz stanowiska zajmowane przez Mieszkowskiego do mobilizacji w sierpniu 1939 r., czego już niestety o działaniach z września i października 1939 r. powiedzieć nie można. Moim zdaniem opis obrony Wybrzeża został tu zbyt skrócony. Istnieje literatura na temat obrony Helu ${ }^{10}$ - szkoda, że autorzy nie wykorzystali jej i nie przytoczyli w swojej książce. Opis obrony gdyńskiego portu czy też działań na cyplu helskim do kapitulacji 2 października 1939 r., w których zasłużył się Mieszkowski byłby doskonałym uzupełnieniem rozdziału.

Rozdział trzeci: W niemieckich oflagach (s. 34-43) jest najkrótszym spośród wszystkich rozdziałów - jak piszą we wstępie autorzy: „skupili się na powojennej działalności kmdr Mieszkowskiego" i pominęli sprawy mniej istotne tj. pobytu w niemieckich oflagach i stalagach dla polskich jeńców wojennych. Podobnie jak w poprzednim rozdziale zdecydowana większość tekstu poświęcona jest zagadnieniom ogólnym dotyczącym organizacji życia jeńców w oflagach, przedstawieniu ich postaci, z niewątpliwie wysuwającą się na pierwszy plan postacią kontradmirała Józefa Unruga ${ }^{11}$. Opisywane wydarzenia z życia $\mathrm{w}$ niewoli jenieckiej niestety nie skupiają się w żaden sposób na osobie Stanisława Mieszkowskiego. Jedyną informacją, jaką o nim otrzymujemy, jest to, iż powrócił do Polski z Oflagu II C Woldenberg wraz z grupą około 4 tys. jeńców. Bardzo krótki rozdział zatytułowany $W$ niemieckich oflagach praktycznie pomija osobę Mieszkowskiego, co powoduje pewien, znaczący wręcz, niedosyt.

Rozdział czwarty: W marynarce wojennej PRL (s. 43-82) to najobszerniejszy rozdział biografii - autorzy podkreślają to także we wstępie, skupiając się głównie na powojennych losach i działalności kmdr. Mieszkowskiego. Po wzmiance o odszukaniu w Łodzi żony oraz syna i krótkim, lecz bez wątpienia owocnym epizodzie, w którym sprawował funkcję kapitana portu w Kołobrzegu (Mieszkowski był pierwszym Polakiem - kapitanem portu w historii miasta), autorzy przedstawiają ponowną służbę Mieszkowskiego

10 J. Pertek, Wielkie dni małej floty, Warszawa 2015; P. Derdej, Westerplatte - Oksywie - Hel 1939, Warszawa 2009; E. Kosiarz, Obrona Helu w 1939, Warszawa 1971.

11 Józef Unrug (ur. 1884 - zm. 1973) kontradmirał, uczestnik wojny polsko-bolszewickiej 1920 r. oraz kampanii wrześniowej 1939 r., dowódca Floty i Obrony Wybrzeża. W latach 1939-1945 więzień niemieckich oflagów m.in.: X B Nienburg, II C Woldenberg, VII A Murnau. Po opuszczeniu oflagów udał się do Wielkiej Brytanii, gdzie brał udział w likwidacji Polskich Sił Zbrojnych na Zachodzie. Do końca życia pozostał na emigracji. Zmarł w Lally-en-Val we Francji w 1973 r. 
jako oficera Marynarki Wojennej. Próba odnalezienia się w nowej - powojennej - rzeczywistości oraz dylematy, z którymi zmagał się bohater recenzowanej biografii, stanowią ważną część rozdziału czwartego oraz początek opisu jego dalszych losów.

Mieszkowski, będąc osobą wychowaną w duchu patriotyzmu, umacniany $\mathrm{w}$ swoich przekonaniach licznymi rozmowami z przedwojennymi oficerami Marynarki Wojennej, postanawia ponownie wstąpić do wojska. Pomimo daleko idących zmian zachodzących w kraju na wszystkich płaszczyznach życia, a będących wynikiem stalinizacji, Mieszkowski z wielkim zapałem włącza się do odbudowy kraju, dając $z$ siebie wszystko, co miał najlepszego do zaoferowania: swoją wiedzę i doświadczenie, pracowitość i autorytet. Pierwszym zadaniem, które zostało powierzone Mieszkowskiemu, było zorganizowanie Flotylli Trałowców. Równolegle do narracji o samym Mieszkowskim autorzy opisują zmiany zachodzące wówczas w Marynarce Wojennej. Dzięki zastosowanemu zabiegowi czytelnik ma możliwość zapoznania się z mechanizmami dowodzenia ówczesnym wojskiem oraz jego uzależnieniem od ZSRR - na przykład wymianą kadr czy też upolitycznieniem stanowisk. Niezwykle istotne jest także przedstawienie struktur władzy ludowej, dzięki którym czytelnik ma szeroki obraz funkcjonowania systemu komunistycznego w Polsce lat powojennych, co - przez wprowadzenie głębszego kontekstu - umożliwia lepsze zrozumienie rzeczywistości, w jakiej funkcjonował komandor.

Następne akapity rozdziału opisują Mieszkowskiego pracującego na stanowisku dyrektora nauk Wydziału Morskiego nowo powstałej Oficerskiej Szkoły Marynarki Wojennej oraz pełniącego obowiązki komendanta OSMW. Rozwój OSMW - jak słusznie przytaczają autorzy - był w dużej mierze zasługą kmdr. ppor. Mieszkowskiego, który jako doświadczony oficer posiadający ogromną wiedzę potrafił je skutecznie przekazać słuchaczom. Po raz kolejny dał się poznać jako osoba godna powierzenia najtrudniejszych zadań.

$\mathrm{Na}$ kolejnych kartach pracy poznajemy dalszą służbę Mieszkowskiego, który pomimo swojego wielkiego talentu i pracowitości ostatecznie nie mógł pozostać na zajmowanych stanowiskach ze względu na bycie „sanacyjnym" oficerem. Awansowany już do stopnia komandora (22 lipca 1948 r.), Mieszkowski został przeniesiony przez ministra obrony narodowej z dniem 1 marca 1949 r. na stanowisko zastępcy dowódcy Marynarki Wojennej do spraw liniowych. Ze względu na niesatysfakcjonujące wyniki pracy (min. braki w wyszkoleniu taktycznym załóg okrętowych i lotniczych) z dniem 1 listopada 1949 r. przeniesiono go na stanowisko dowódcy Floty. Jak się miało okazać, było ono ostatnim, jakie przyszło piastować Mieszkowskiemu w swoim życiu.

Nowa władza sukcesywnie wykorzystywała, a następnie eliminowała swoich przeciwników. Również tych, którzy bez wątpienia przyczyniali się do 
odbudowy zarówno państwa, jak i struktur wojskowych. Kluczowe w perspektywie Mieszkowskiego okazało się zatwierdzenie przez Główny Zarząd Informacji WP planu operacyjnego zmierzającego do rozpoznania i rozpracowania przedwojennych oficerów będących jeńcami obozu II C Woldenberg pełniących służbę zawodową w WP z 8 listopada 1949 r. Inwigilacja dotyczyła także Mieszkowskiego i ostatecznie doprowadziła do jego aresztowania 20 października 1950 r. pod fałszywym zarzutem udziału w antypaństwowej konspiracji. Podobny los spotkał innych oficerów MW: kmdr. por. Zbigniewa Przybyszewskiego (ur. 1907 - zm. 1952), kmdr. Jerzego Staniewicza (ur. 1903 - zm. 1952), kmdr. por. Roberta Kasperskiego (ur. 1907 - zm. 1974), kmdr. por. Wacława Krzywca (ur. 1908 - zm. 1956), kmdr. pil. Kazimierza Kraszewskiego (ur. 1910 - zm. 1990), kmdr. por. Adama Rychla (ur. 1909 - zm. 1958) oraz kmdr. Mariana Wojcieszka (ur. 1901 - zm. 1974)12. Jak się później okaże, Staniewicz i Przybyszewski zostaną po latach (w 2013 r.) odnalezieni wraz z Mieszkowskim we wspólnym dole śmierci na kwaterze $€$ - „Łączce” na warszawskich Powązkach ${ }^{13}$.

Rozdział piąty: Aresztowanie, śledztwo i wyrok (s. 83-96) stanowi opis wydarzeń z życia Mieszkowskiego, począwszy od 20 października 1950 r., tj. od dnia jego aresztowania. Jest to niezwykle trudna i zarazem istotna część publikacji - znamienne i godne uwagi oraz zapamiętania są wypowiedzi Witolda Mieszkowskiego - syna komandora, który przez wiele lat dociekał prawdy i sprawiedliwości po zamordowaniu swojego ojca. Niezwykle plastyczne opisy i trafność ocen Witolda Mieszkowskiego doskonale uzupełniają narrację autorów i stanowią cenne źródło dla badaczy losów osób skazanych na karę śmierci w procesach politycznych epoki stalinizmu.

\footnotetext{
12 P. Semków, $W$ morzu Twoja droga. Oficerowie, podoficerowie i marynarze $M W$ represjonowani w czasach polskiego stalinizmu, Gdańsk-Warszawa 2017.

13 Szczątki kmdr. Mieszkowskiego zostały odnalezione w 2013 r. podczas drugiego etapu prac ekshumacyjno-poszukiwawczych prowadzonych przez Instytut Pamięci Narodowej w ramach ogólnopolskiego programu poszukiwań tajnych miejsc pochówku ofiar totalitaryzmów. W dniach 13 V 2013 r. - 4 VI 2013 r. zespół pod przewodnictwem dr. hab. Krzysztofa Szwagrzyka przebadał kolejny fragment kwatery „Ł” cmentarza Powązki Wojskowe w Warszawie i wydobył z ziemi łącznie szczątki 82 osób. Większość z nich została odnaleziona pod asfaltową drogą przylegającą do „Łączki”. W jednym z masowych grobów (oznaczony symbolem AE) pod drogą asfaltową odnaleziono szczątki kmdr. Mieszkowskiego, kmdr. por. Przybyszewskiego oraz kmdr. Staniewicza. 28 II 2014 r. podczas konferencji identyfikacyjnej w Pałacu Prezydenckim w Warszawie podano do publicznej wiadomości identyfikację Mieszkowskiego oraz Przybyszewskiego. Nazwisko Staniewicza zostało ogłoszone podczas konferencji identyfikacyjnej 9 VI 2016 r. W 65 rocznicę stracenia komandorów, w dniach 15-16 XII 2017 r., na Helu i w Gdyni odbyły się uroczystości pogrzebowe. Postanowieniem Prezydenta RP na wniosek ministra obrony narodowej na stopień kontradmirała pośmiertnie został mianowany Jerzy Staniewicz, wcześniej pośmiertnym awansem na stopień kontradmirała awansowano Stanisława Mieszkowskiego. Szczątki komandorów spoczęły na cmentarzu Marynarki Wojennej w Gdyni-Oksywiu.
} 
Opisywane tortury i metody działań oficerów śledczych GZI przedstawiają nam brutalną prawdę traktowania nawet najwyższych stopniem oficerów Marynarki Wojennej oskarżonych o szpiegostwo i działalność antypaństwową (podobne działania GZI były skierowane przeciwko oficerom ludowego Wojska Polskiego oskarżonym o szpiegostwo ${ }^{14}$ ). Autorzy, nie mając pewności co do metod stosowanych wobec Mieszkowskiego, przywołują przypadek kmdr. Mariana Wojcieszka - współwięźnia, dręczonego i maltretowanego przez kolejne tygodnie, co doprowadziło do halucynacji i obłąkania. „Wypróbowane metody śledcze”, wymuszone zeznania prowadzące do procesu sądowego, przytaczane nazwiska prowadzących śledztwo funkcjonariuszy oraz prokuratorów i sędziów dają czytelnikowi niezwykły ogląd dramatycznej sytuacji obrońcy Helu. Dzięki wskazaniu nazwisk, instytucji oraz faktów czytelnik ma możliwość dokładnego przeanalizowania - krok po kroku - typowych działań służb bezpieczeństwa PRL względem obywateli. Wobec uderzających opisów metod stosowanych wobec zasłużonych dla II Rzeczypospolitej oficerów nie sposób pozostać obojętnym. Pozbawienie życia Mieszkowskiego tzw. „metodą katyńską”, wieloletnie szykany skierowane przeciw wdowie i synowi, próby dociekania prawdy stanowią ważną część zakończenia; śmierć nie jest tu bowiem końcem historii - kolejnymi jej etapami jest wspomniana walka rodzin o prawdę oraz próby upamiętnienia m.in. komandora Mieszkowskiego.

Podsumowując, AMOR PATRIAE NOSTRA LEX Rzecz o komandorze Stanisławie Mieszkowskim jest pozycją ważną, przybliżającą życiorys jednego z najbardziej zasłużonych oficerów Marynarki Wojennej RP. Opracowanie - jak piszą sami autorzy - nie będąc dziełem naukowym w ścisłym tego słowa znaczeniu i dzięki swojej przystępnej formie, jest adresowane do szerokiego gremium odbiorców - nawet tych, którzy do tej pory nie interesowali się historią Marynarki Wojennej czy też procesami politycznymi epoki stalinizmu. Uważam to za bardzo dobry zabieg, dzięki któremu książka może trafić to wielu czytelników.

Minusami tej ważnej pozycji, w moim odczuciu, są: brak szczegółowego opisu działań Mieszkowskiego w rozdziałach II i III oraz stosunkowo nieduża objętość książki. Nieopisanie wydarzeń obrony Wybrzeża oraz pobytu Mieszkowskiego w oflagach (szczególnie w II C Woldenberg) to moim zdaniem największy zarzut. Niestety, nie dowiadujemy się, co wówczas robił Mieszkowski i pozostawia to - sygnalizowany przeze mnie - znaczący niedosyt. $\mathrm{Z}$ innych pozycji ${ }^{15}$ zaś możemy się dowiedzieć m.in. tego, że podczas

\footnotetext{
14 J. Poksiński, „TUN” Tatar - Utnik - Nowicki, Warszawa 1992.

15 H. Kroczyński, Lata szkolne i służba w Marynarce Wojennej II RP [w:] Kmdr Stanisław Mieszkowski - Pierwszy polski kapitan Portu Kołobrzeg, red. H. Kroczyński, Kołobrzeg 2009.
} 
pobytu w oflagu Mieszkowski wykładał język rosyjski czy też kierował sekcją rekwizytów teatralnych.

Mimo zaznaczenia we wstępie, iż pominięto okres niewoli, brak przytoczenia jakichkolwiek informacji w tym kontekście na temat Mieszkowskiego uważam za duży minus w publikacji. Nawet najmniejsza wzmianka, osobisty akcent na temat Mieszkowskiego byłby satysfakcjonujący dla czytelnika.

Brak opisu wydarzeń z okresu 1940-1945, tj. do czasu wyzwolenia Oflagu II C Woldenberg, wpłynął zatem na objętość pracy. Można śmiało powiedzieć, że jest to raczej obszerne, popularne wydanie broszurowe. Pomimo wspomnianych minusów książka stanowi bardzo dobry „punkt wejścia” pretekst do sięgnięcia po inne tytuły traktujące o obronie Helu czy też np. powojennych losach polskich komandorów ${ }^{16}$.

Kończąc, należy odnieść się jeszcze do kwestii technicznych i edycyjnych, które również mają znaczenie dla odbioru pozycji. Książka napisana jest spójnie, przypisy pozostawione na dolnych częściach stron dają wygodne odniesienia do źródeł, wartościowym uzupełnieniem są fotografie umieszczone na końcu publikacji. Jest to książka jak najbardziej warta polecenia - będąca również formą upamiętnienia zasłużonego oficera Marynarki Wojennej okresu II Rzeczpospolitej oraz lat 1945-1950.

Rafał Michliński

16 H. Kowalska, Sadownictwo w Marynarce Wojennej w latach 1945-1955, Gdańsk-Warszawa 2017. 